\title{
SCIENTIFIC REPORTS

\section{Determining nitrogen isotopes discrimination under drought stress on enzymatic activities, nitrogen isotope abundance and water contents of Kentucky bluegrass}

\begin{abstract}
Shah Saud ${ }^{1,6}$, Shah Fahad ${ }^{2,3,6}$, Guowen Cui ${ }^{4}$, Chen Yajun ${ }^{1 *}$ \& Sumera Anwar ${ }^{3,5}$
Drought stress is the most pervasive threat to plant growth, which predominantly encumbers turf grass growth by causing alterations in plant functions. This study appraised the role of nitrogen isotopes in providing a theoretical basis for developing and improving Kentucky bluegrass cultivar performance under drought stress. Nitrogen isotopes labelled ${ }^{15} \mathrm{NH}_{4} \mathrm{Cl}$ and $\mathrm{K}^{15} \mathrm{NO}_{3}$ were prepared to replace $\mathrm{KNO}_{3}$ in Hoagland's solution at concentrations of ${ }^{15} \mathrm{NH}_{4}{ }^{+}$and ${ }^{15} \mathrm{NO}_{3}$ at 1.5, 15 , and $30 \mathrm{mM}$; the solutions were imposed on stressed plants under glasshouse conditions. Nitrogenous nutrition reduced oxidative stress by elevating the enzymatic activities and proline contents of all three clonal ramet leaves, particularly under stress conditions. Apart from nitrogen content, nitrogen isotope abundance, relative water content and water potential within controls were enhanced in treated with ${ }^{15} \mathrm{NH}_{4}{ }^{+}$than in with ${ }^{15} \mathrm{NO}_{3}$ in both the roots and leaves of Kentucky bluegrass. Nevertheless, an application of ${ }^{15} \mathrm{NH}_{4} \mathrm{Cl}$ and $\mathrm{K}^{15} \mathrm{NO}_{3}$ at $30 \mathrm{mM}$ had a positive influence to some extent on these attributes under drought stress. Overall, our results suggested that nitrogen isotopes contributed to drought tolerance in all three clonal ramets of Kentucky bluegrass by maintaining a better osmoprotectant and antioxidant defence system, which helped the plants eliminate reactive oxygen species.
\end{abstract}

Climate change models predict that rising atmospheric $\mathrm{CO}_{2}$ partial pressure during the next 100 years will cause average surface temperatures to rise by $1-3.5^{\circ} \mathrm{C}$ in mid-latitude regions $s^{1,2}$. As a result, changes will occur in precipitation and evaporation patterns, and ecosystems will be exposed to more frequent drought events ${ }^{2,3}$. Furthermore, a persistent aridity enlargement has been recorded since the middle of the 20th century, and according to present projection models, this process will continue ${ }^{4}$. In some regions where a declination is predicted in crop performance, many advances have to be developed in plant breeding programmes and agricultural technology ${ }^{5}$. Understanding the adaption and response of drought and their mechanisms is essential for the achievement of those aims.

In water scarce areas, drought stress is considered one of the most devastating abiotic stresses for turf grass performance. Water stress happens in the crop either when the supply of water to the roots is intermittent or when the rate of transpiration goes beyond their optimum range, and under arid and semi-arid climate regions, these two conditions frequently coincide. The circumstances become further intensified due to the receding water table and mounting global warming. Plant adaptive strategies to drought stress are very multifaceted but not mutually exclusive, in practice, plants may combine a range of response types ${ }^{6}$. Literatures have addressed many important physiological and biochemical mechanisms of plants resistance to drought, such as the role of antioxidant enzymes, osmotic adjustment, membrane proteins mediating ions transports ${ }^{7-12}$. Often in plants,

${ }^{1}$ College of Horticulture, Northeast Agricultural University Harbin, 150030, Heilongjiang, China. ${ }^{2}$ Department of Agriculture, University of Swabi, Khyber Pakhtunkhwa, Pakistan. ${ }^{3}$ College of Plant Science and Technology, Huazhong Agricultural University, Wuhan, Hubei, 430070, China. ${ }^{4}$ College of Animal Sciences and Technology, Northeast Agricultural University Harbin, 150030, Heilongjiang, China. ${ }^{5}$ Institute of Molecular Biology and Biotechnology. The University of Lahore, Lahore, Pakistan. ${ }^{6}$ These authors contributed equally: Shah Saud and Shah Fahad. *email: chenyajun622@163.com 
these detoxification (SOD, POD, CAT), osmoprotection (proline, sugar), ions movement and genes regulation are synergistic resistance to drought resistance ${ }^{13}$. In fact, plants suffered water deficit induce a decrease in nutrients assimilation, in particular nitrogen, with strong interactive effects on plant growth and performance ${ }^{14}$.

Some clonal plants ${ }^{15}$ with unique ramets system by interval connected to each other adapt to severe environment through phenotypic plasticity and physiological integration allowing water and nutrients transfer and redistribution between the clonal ramets. During nutrient transport process, water is the main carrier. However, the directions and the extent of the integration of water and nutrients physiology of clonal plants are different ${ }^{16}$. Kentucky bluegrass (Poa pratensis L.) is a typical clonal plant which spreads by rhizomes and tillers and produces many ramets in its clonal system ${ }^{17}$. It is also an excellent perennial cold season turfgrass. When temperatures are optimal $\left(18\right.$ to $24^{\circ} \mathrm{C}$ ), along with an adequate amount of water and proper nutrient management, it forms an attractive turf; nevertheless, rapid colour loss, thinning, and dormancy are observed during periods of prolonged heat and water stress situations ${ }^{18}$. Water scarcity, along with low nitrogen $(\mathrm{N})$, is an important constraint to Kentucky bluegrass performance, and has broadly been documented in influencing leaf water relations and photosynthetic attributes that result in decreased plant growth rate, early senescence, and poor plant efficiency ${ }^{10,19-21}$. An appropriate amount of nitrogen can have a significant effect on controlling turf grass density and weeds, and it is good to extend the turf grass green period and advance the re-greening period ${ }^{22}$. Leaf width and length are determined by genetic genes, but the appearance quality of turf grass is correlated with the amount of nitrogen fertilizer ${ }^{23}$ In general, former studies focus on individual plant, information on nutrients translocation and physiological responses to drought stress between ramets system of Kentucky bluegrass is lacking. Understanding the physiological adaptation of clonal ramets system of Kentucky bluegrass to drought stress may provide improved selection traits for breeding programs, leading to cultivars with good clonal attributes based drought resistance.

An adequate evaluation of drought stress influence under different $\mathrm{N}$ isotopic levels on physiological attributes can provide a better understanding of Kentucky bluegrass under drought stress ${ }^{24}$ Stable isotope methods have been utilized as tools that deliver valuable information on factors affecting plant growth, for instasnce, transpiration efficacy and the ratio of net photosynthesis to transpired water, among others, and those that integrate the duration through which $\mathrm{CO}_{2}$ is assimilated ${ }^{25-27}$. Variations in ${ }^{15} \mathrm{~N}$ isotopic composition $\left(\delta^{15} \mathrm{~N}\right)$ have also been suggested as a beneficial feature for crop screening ${ }^{28,29}$. Robinson et al..$^{30}$ documented that the natural profusion of ${ }^{15} \mathrm{~N}$ might play a vital role in the responses to numerous abiotic stresses such as drought and nitrogen starvation. Furthermore, $\delta^{13} \mathrm{C}$ and $\delta^{15} \mathrm{~N}$ have been utilized to illustrate plant responses to salinity stress ${ }^{31}$ and are broadly used in plant ecophysiology to evaluate the consequences of varying climatic due to their sensitivity sensitive to environmental constraints $\mathrm{s}^{32} \mathrm{In}$ addition, variations in $\mathrm{N}$ source and the distribution of $\mathrm{N}$ assimilation between the roots and shoots are known to affect intra-plant changes in $\delta^{15} \mathrm{~N}^{33}$. Therefore, assessing $\mathrm{N}$ isotopes in several plant parts can provide new insights into drought influences on nitrogen metabolism inside Kentucky bluegrass plants.

Currently, most studies related to Kentucky bluegrasses focus on nitrogen uptake, metabolism and utilization efficiency under conditions of no stress, and despite recent advances in the understanding of plant $\delta^{15} \mathrm{~N}$, there are no reports about the physiological integration of isotopic nitrogen in clonal populations of Kentucky bluegrass under heterogeneous ecological conditions. Therefore, the objectives of this study were (1) to determine the role of nitrogen tracers as an indicator of stress for Kentucky bluegrass, (2) to explore nitrogen isotopes influence on the physiological traits of ramets, and (3) to investigate the potential interference of nitrogen tracers on nitrogen isotope abundance and nitrogen content in both the roots and leaves of Kentucky bluegrasses, all of which can provide valuable information on the transport and metabolism of nitrogen under drought conditions.

\section{Materials and Methods}

Plant Material and growth conditions. Sod (10-cm diameter) of Kentucky bluegrass cv. "Arcadia" was collected from a turf field with a metal hollow drill on the sixth of June, 2014. Arcadia is a renowned, low water and nitrogen input cultivar and can acclimatize to the climatic and environment conditions in North China. Grasses were first grown in seedling trays $(70 \mathrm{~cm} \times 30 \mathrm{~cm} \times 10 \mathrm{~cm})$, and after 5 days of germination and with the appearance of first two leaves, seedlings were transplanted to pots. During this period, the average daily day and night temperatures were $25 \pm 2$ and $15 \pm 2{ }^{\circ} \mathrm{C}$, respectively. Relative humidity was $60 \pm 5 \%$, and natural sunlight at $700 \pm 10 \mu \mathrm{mol} \mathrm{m}^{-2} \mathrm{~s}^{-1}$ was maintained.

Three identical growing ramets were selected as the research materials from a genetically identical clone population from the early seedlings ${ }^{34}$. Fresh mass and morphological properties of the ramets (rhizome length and plant height) were determined before treatment. The ramets were classified as either a proximal ramet (PR) for the close distance between the ramet and the donor plant, as a distal ramet (DR) for having rhizomes, or as a middle ramet (MR), which is in the middle of the three ramets. Three plastic pots were prepared (length $\times$ width $\times$ height $=10 \mathrm{~cm} \times 10 \mathrm{~cm} \times 20 \mathrm{~cm}$ ) and filled with fine sand to a height of $18 \mathrm{~cm}$ (particle size was between 0.2 and $1.0 \mathrm{~mm}$ ). Subsequently, a slit was cut down from the edge of the pot and a hole was drilled at the very end of each slit. Three sub strains of plant material were planted into pots separately, which were connected through the holes via connected rhizomes and were sealed from neighbouring pots by glue to avoid water, sand and nutrient loss. Rhizomes were covered by $5 \mathrm{~cm}$ sand and surrounded by dark PE film to avoid sun light. Plants were irrigated by Hoagland's solution every two days and then irrigated by deionized water periodically for the rest of the days.

Treatments. Nitrogen sources including $\mathrm{NH}_{4} \mathrm{Cl}, \mathrm{KNO}_{3}$, isotopes $\left(\delta^{15} \mathrm{~N}\right)$ labelled ${ }^{15} \mathrm{NH}_{4} \mathrm{Cl}$ and $\mathrm{K}^{15} \mathrm{NO}_{3}$ were prepared using Hoagland's solution at the concentrations of 1.5, 15, and $30 \mathrm{mM} \mathrm{NH}_{4}^{+}, \mathrm{NO}_{3}^{-},{ }^{15} \mathrm{NH}_{4}^{+}$and ${ }^{15} \mathrm{NO}_{3}^{-}$. For drought stress conditions, PEG6000 was added to the solutions and was adjusted to an osmotic potential of $-1.0 \mathrm{Mpa}$, while the solutions of the controls without PEG6000 had an osmotic potential of $-0.03 \mathrm{Mpa}$. The Root-DS and Leaf-DS represented the parameters of the roots and leaves under drought stress, and Root-CK and Leaf-CK as control groups represented the parameters under no drought conditions. Each treatment was taken in four replicates during whole experiment. After 2 weeks of cultivation, the three plants connected by rhizome were 


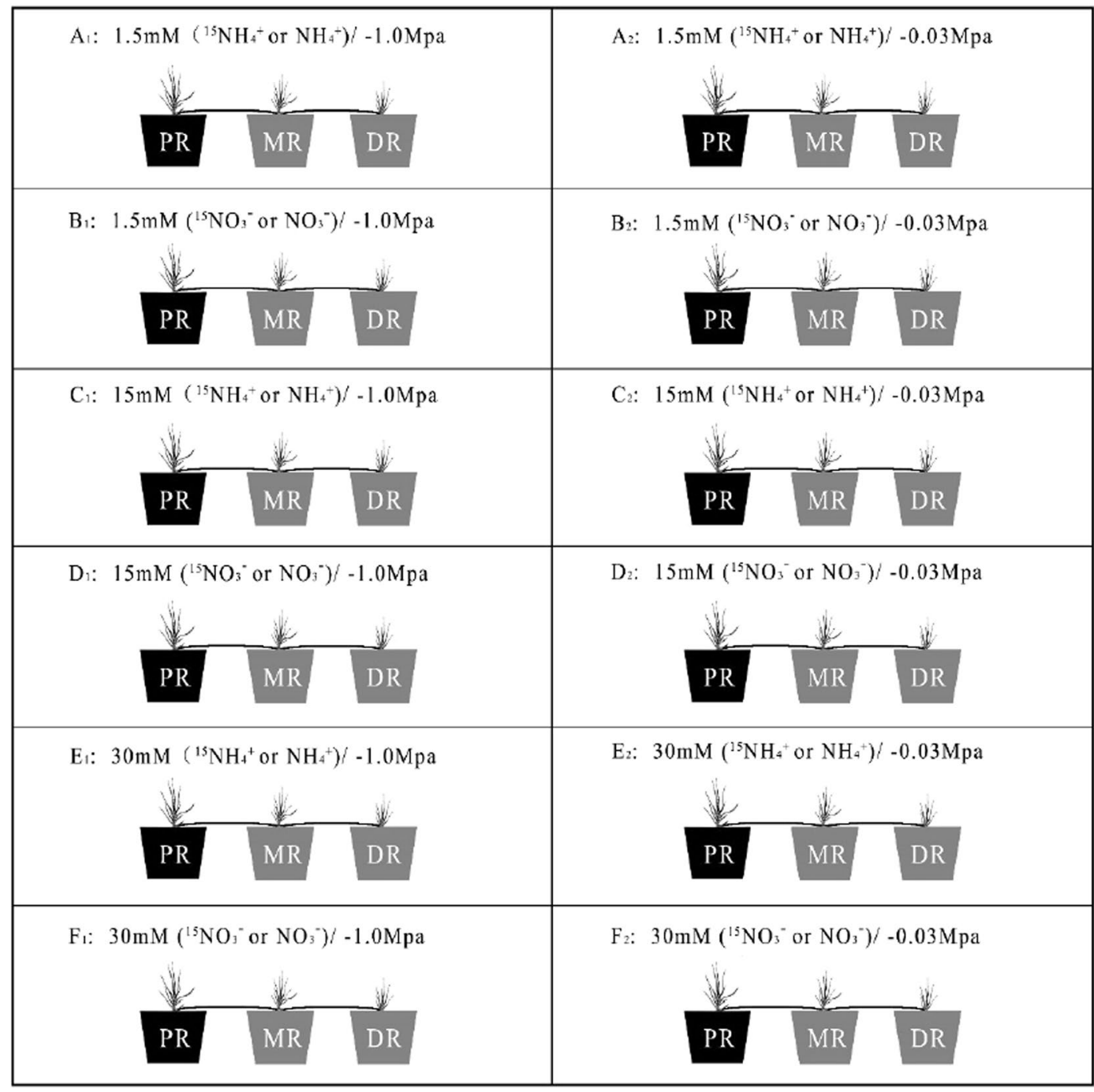

Figure 1. Schematic representation of the experimental treatments with three concentrations $(1.5 \mathrm{mM}, 15 \mathrm{mM}$ and $30 \mathrm{mM}$ ) of nitrogen $\left({ }^{15} \mathrm{NH}_{4}{ }^{+}, \mathrm{NH}_{4}{ }^{+},{ }^{15} \mathrm{NO}_{3}{ }^{-}\right.$and $\left.\mathrm{NO}_{3}{ }^{-}\right)$under normal water (Osmotic potential of the solutions of $A_{1}, B_{1}, C_{1}, D_{1}, E_{1}$ and $F_{1}$ was $-0.03 \mathrm{Mpa}$ ) and drought (Osmotic potential of the solutions of $A_{2}$, $\mathrm{B}_{2}, \mathrm{C}_{2}, \mathrm{D}_{2}, \mathrm{E}_{2}$ and $\mathrm{F}_{2}$ was $-0.1 \mathrm{Mpa}$ ) conditions were imposed on Kentucky bluegrass ramets (PR, MR and DR). Solutions with ${ }^{15} \mathrm{NH}_{4}{ }^{+}$or ${ }^{15} \mathrm{NO}_{3}{ }^{-}$were added into the black beakers (PR) in each group. Grey beakers holding with $\mathrm{MR}$ and $\mathrm{DR}$ in the same group were added with either $\mathrm{NH}_{4}{ }^{+}$or $\mathrm{NO}_{3}{ }^{-}$in the same concentration. $\mathrm{PR}, \mathrm{MR}$ and DR were connected by rhizome.

obtained by removing the sand and cutting the root bottoms without destroying the rhizome. The roots of three ramets were washed with distilled water, dried by filter paper, and cultured in three beakers ( $50 \mathrm{ml})$ separately as shown in Fig. 1.

The designated solution with $\delta^{15} \mathrm{~N}$ at specific concentration was added into the beaker with PR, while the other two beakers holding with MR and DR in the same group were added with either $\mathrm{NH}_{4}{ }^{+}$or $\mathrm{NO}_{3}{ }^{-}$in the same concentration. After $48 \mathrm{~h}$ treated rhizome connected with ramets system of PR, MR and DR, leaves and roots of these ramets were taken for parameters measurement.

Data collection. $\quad N$ isotope and $N$ contents analysis. The abundance of $\delta^{15} \mathrm{~N}$ isotopes from the roots and leaf of different ramets were determined by EA-IRMS (EA: vario MICRO cube, Elemental, Germany; IRMS: IsoPrime100, Iso Prime, England). The roots and leaf materials were oven-dried and ground separately and were transferred into small tin capsules in an element analyser tray. They were oxidized into nitrogen oxide and $\mathrm{CO}_{2}$ at $950{ }^{\circ} \mathrm{C}$, and afterwards, $\mathrm{NO}_{\mathrm{X}}$ was reduced to $\mathrm{N}_{2}$ at $550^{\circ} \mathrm{C}$ with $\mathrm{CO}_{2}$ absorbed on the desorption column, and $\mathrm{N}_{2}$ entered into the analyser system for analysis. Both the amount of $\mathrm{N}$ (expressed by mass percentage) and the abundance of isotopes were obtained. $\mathrm{N}$ content was also determined by the standard macro-Kjeldahl procedure using a Kjeltec 2300 analyser unit (Foss Tecator AB, Hoganas, Sweden). Both roots and leaf samples were ground to powder, weighed $(\sim 0.1 \mathrm{~g}$ each $)$ and then digested in $\mathrm{H}_{2} \mathrm{SO}_{4}-\mathrm{H}_{2} \mathrm{O}_{2}$. 
Antioxidants. The activity of superoxide dismutase (SOD) was assayed following the method described by ${ }^{35}$ Peroxidase (POD) and Catalase (CAT) activities were also assayed following the method described by Bai et al. ${ }^{35}$. The $3 \mathrm{ml}$ reaction solution for POD contained $50 \mathrm{mM}$ phosphate buffer ( $\mathrm{pH} 7.8$ ), $25 \mathrm{mM}$ guaiacol, $200 \mathrm{mM} \mathrm{H}_{2} \mathrm{O}_{2}$, and $0.5 \mathrm{ml}$ enzyme extract. One unit of POD activity was determined as 0.01 units/min change in absorbance.

Relative water content $(R W C)$, water potential $(\Psi w)$, and Proline. Relative water content (RWC) of both leaves and roots were determined based on fresh (FW), turgid (TW), and dry weights (DW) using the following formula: RWC $(\%)=[(\mathrm{FW}-\mathrm{DW}) /(\mathrm{TW}-\mathrm{DW})] \times 100$. The leaf and root water potential $(\Psi \mathrm{w})$ were determined following the method of Bruggink and Huang ${ }^{36}$ by using a pressure chamber (PMS Instrument Co., Corvallis, OR, USA). While proline content was determined according to Gilmour et al. ${ }^{37}$.

Experimental design and statistical analyses. The experiment was carried out using a complete randomized design (CRD) with four replicates. Data were analysed by analysis of variance using SPSS v 9.0 software (SPSS, Inc., Chicago IL). The mean values were compared with a least significance difference test at a 0.05 probability level. Mean graphs were made using Sigma plot v.10 (Systat Software, San Jose, CA) ${ }^{38}$.

\section{Results}

Changes in catalase activity in the clonal ramets of Kentucky bluegrass under different nitrogen tracers and water supplies. Drought stress under various levels of fertilization significantly affected the catalase activities of the proximal ramets (PR) and the distal ramets (DR) compared to the middle ramets (MR) in all treatments (Fig. 2). An application of $\mathrm{NH}_{4} \mathrm{Cl}$ at $1.5 \mathrm{mM}$ showed an increase in PR, MR, and DR of $17 \%, 44 \%$, and $42 \%$, respectively; however, with $\mathrm{KNO}_{3}$, an increase of $20 \%, 28 \%$ and $17 \%$ was observed, respectively, compared to well-watered conditions (Fig. 2a,b). The fertilization of $\mathrm{NH}_{4} \mathrm{Cl}$ and $\mathrm{KNO}_{3}$ was beneficial under drought stress, and both fertilizers applied at $15 \mathrm{mM}$ recorded an increase of $16 \%$ and $5 \%$ in DR, respectively, while in MR and PR, there was a $2 \%$ and $10 \%$ reduction in catalase activity with the $\mathrm{KNO}_{3}$ treatment compared to the control, respectively (Fig. 2c,d). Furthermore, it was noted that the catalase activity in all treatments of PR, $\mathrm{DR}$, and $\mathrm{MR}$ under the high level of $30 \mathrm{Mm} \mathrm{NH}_{4} \mathrm{Cl}$ applications declined abruptly when Kentucky bluegrass was exposed to drought stress (Fig. 2e). The data pertaining to PR, MR, and DR indicated a reduction of 38\%, 26\% and $26 \%$, respectively, under drought conditions. Among all three attributes, MR was the least influenced, followed by DR and PR. An increase in the catalase activity of Kentucky bluegrass was proportional to the rate of $\mathrm{KNO}_{3}$, and $\mathrm{KNO}_{3}$ at $30 \mathrm{mM}$ recorded the highest activity (Fig. 2f). Drought stress enhanced the activity of all three attributes, as this treatment increased the activity of MR (35\%), followed by PR (29\%) and DR (20\%). The overall fertilization of $\mathrm{NH}_{4} \mathrm{Cl}$ and $\mathrm{KNO}_{3}$ at $30 \mathrm{mM}$ increased the catalase activity of all three attributes, as shown in Fig. 2.

Changes in SOD in the clonal ramets of Kentucky bluegrass under different nitrogen tracers and water supplies. Superoxide dismutase (SOD) activity in Kentucky bluegrass was severely influenced by the fertilization of $\mathrm{NH}_{4} \mathrm{Cl}$ and $\mathrm{KNO}_{3}$ under drought stress conditions (Fig. 3). An application of $\mathrm{NH}_{4} \mathrm{Cl}_{\text {and }} \mathrm{KNO}_{3}$ at $1.5 \mathrm{mM}$ significantly and linearly increased the activity of $\mathrm{PR}, \mathrm{MR}$, and DR; nevertheless, among the traits we examined, $\mathrm{PR}$ and $\mathrm{MR}$ in $\mathrm{NH}_{4} \mathrm{Cl}$ was increased $66 \%$ and 52\%, respectively, while MR and $\mathrm{DR}$ in $\mathrm{KNO}_{3}$ had the highest SOD activity (Fig. 3a,b). Among the control, DR followed by MR had the highest activity. We addressed the impact of moderate levels of nitrogenous fertilizer on SOD activity in the three traits of Kentucky bluegrass. All PR, MR, and DR showed increased activity under drought stress at $15 \mathrm{mM}^{\circ} \mathrm{NH}_{4} \mathrm{Cl}$. MR followed by PR and then DR were the best, giving a maximum enhancement of $43 \%, 32 \%$ and $23 \%$, respectively (Fig. 3c). An application of $15 \mathrm{mM}$ of $\mathrm{KNO}_{3}$ remained effective in alleviating the adverse influence of drought stress but was not as effective as $\mathrm{NH}_{4} \mathrm{Cl}$. Compared to the control, $\mathrm{PR}, \mathrm{MR}$, and $\mathrm{DR}$ recorded $13 \%, 4 \%$ and $3 \%$ less activity in Kentucky bluegrass, respectively (Fig. 3d). A non-significant effect was recorded with the high level of $\mathrm{NH}_{4} \mathrm{Cl}$ at $30 \mathrm{mM}$ in all the three grass characters when the plants were subjected to water stress conditions. Among the three attributes, PR demonstrated an increase of $32 \%$, followed by MR (15\%), while on the other side, DR decreased by $27 \%$ (Fig. 3e). An application of $\mathrm{KNO}_{3}$ at $30 \mathrm{mM}$ had a less pronounced effect on the activity of all three traits. The $\mathrm{KNO}_{3}$ treatment exhibited a $29 \%, 13 \%$ and $10 \%$ decline in the SOD activity of PR, MR, and DR, respectively, compared to the control treatment without a high dose of fertilizer (Fig. 3f).

Changes in POD in the clonal ramets of Kentucky bluegrass under different nitrogen tracers and water supplies. The data regarding peroxidase (POD) activity of Kentucky bluegrass revealed that the activity of all three traits was influenced by the different levels of nitrogenous fertilizer during progressive drought stress (Fig. 4). A non-significant decrease was observed with the application of $\mathrm{NH}_{4} \mathrm{Cl}$ at $1.5 \mathrm{mM}$; however, this reduction was more distinct in DR (16\%), followed by MR (1\%), as shown in Fig. 4a. Similarly, the PR showed an increased level of $6 \%$ in POD activity compared to the control. We observed that the $\mathrm{KNO}_{3}$ treatment at $1.5 \mathrm{mM}$ enhanced the activity of all attributes of Kentucky bluegrass leaves under drought stress (Fig. 4b). All three traits recorded lower activity under control conditions; however, the $\mathrm{KNO}_{3}$ treatment under drought stress led to the increase in POD activity up to $39 \%, 1 \%$ and $27 \%$ in PR, MR, and DR, respectively. The fertilization of $\mathrm{NH}_{4} \mathrm{Cl}$ and $\mathrm{KNO}_{3}$ at $15 \mathrm{mM}$ remained less beneficial under drought stress than the control treatment (Fig. 4c,d). Both PR and MR showed less activity in response to the fertilization treatments under drought stress conditions, while DR was enhanced by $7 \%$ and $25 \%$ in $\mathrm{NH}_{4} \mathrm{Cl}$ and $\mathrm{KNO}_{3}$, respectively. An application of $\mathrm{NH}_{4} \mathrm{Cl}$ and $\mathrm{KNO}_{3}$ treatments at $30 \mathrm{mM}$ enhanced the activity in MR by $28 \%$ and $21 \%$ under exposure to progressive drought stress, respectively, whereas PR and DR decreased in $\mathrm{NH}_{4} \mathrm{Cl}\left(19 \%\right.$ and $1 \%$, respectively) and only PR $(0.5 \%)$ decreased in $\mathrm{KNO}_{3}$ compared to the control (Fig. 4e,f). 

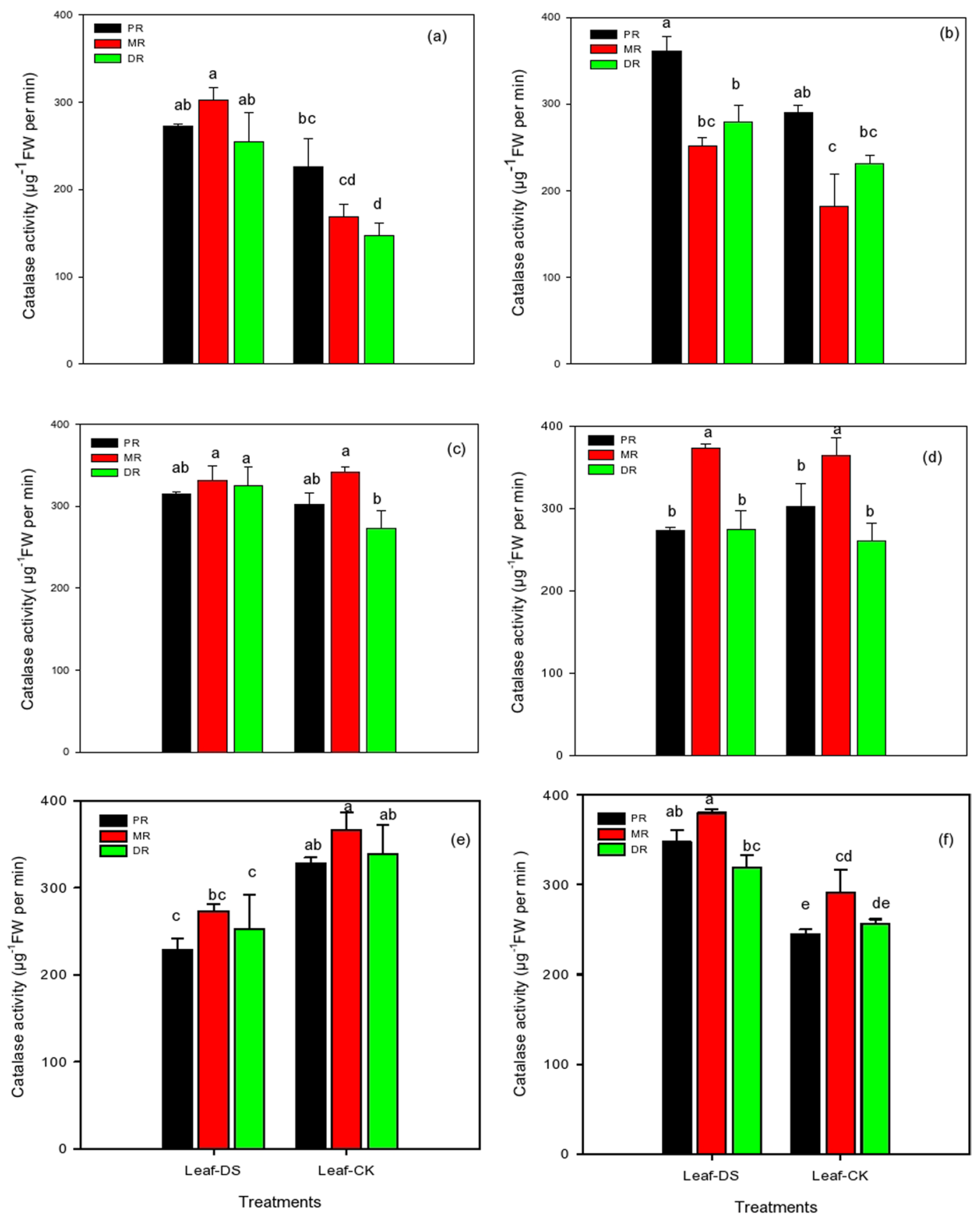

Figure 2. Catalase activity in the clonal ramets of Kentucky bluegrass as affected by drought stress under three nitrogen isotopes at low, moderate and high rates. (a) ${ }^{15} \mathrm{NH}_{4} \mathrm{Cl}$ at $1.5 \mathrm{mM}$, (b) $\mathrm{K}^{15} \mathrm{NO}_{3}$ at $1.5 \mathrm{mM},(\mathbf{c}){ }^{15} \mathrm{NH}_{4} \mathrm{Cl}_{\text {at }}$ $15 \mathrm{mM}$, (d) $\mathrm{K}^{15} \mathrm{NO}_{3}$ at $15 \mathrm{mM}$, (e) ${ }^{15} \mathrm{NH}_{4} \mathrm{Cl}$ at $30 \mathrm{mM}$, and (f) $\mathrm{K}^{15} \mathrm{NO}_{3}$ at $30 \mathrm{Mm}$.

Proline in the clonal ramets of Kentucky bluegrass under different nitrogen tracers and water supplies. The proline content in PR, MR, and DR leaves exhibited at rapid rise under the different levels of nitrogen tracers; however, a decline was observed only at $15 \mathrm{mM}_{\text {of }} \mathrm{NH}_{4} \mathrm{Cl}$ under drought stress (Fig. 5). $\mathrm{NH}_{4} \mathrm{Cl}$ treated plants at $1.5 \mathrm{mM}$ increased the proline levels of PR, MR, and DR up to $18 \%, 10 \%$ and $4 \%$, respectively. Among all three traits, PR performed well in response to fertilizer treatments under water stress conditions (Fig. 5a). Similar trends were observed using $\mathrm{KNO}_{3}$ at $1.5 \mathrm{mM}$, which led to a concomitant increase in proline content in all three attributes of Kentucky bluegrass leaves. Fertilization with $\mathrm{KNO}_{3}$ increased the proline content of MR leaves up 37\%, followed by PR (17\%) and then DR (15\%), as shown in Fig. 5b. The $\mathrm{NH}_{4} \mathrm{Cl}$ treatment at $15 \mathrm{mM}$ retarded proline content in all three traits in comparison with the control. Figure (5c) revealed that the $\mathrm{NH}_{4} \mathrm{Cl}$ treatment caused a decrease in $\mathrm{MR}$ proline content up to 33\%, but this reduction was much lower in DR under drought stress conditions. Through the use of a moderate level of $\mathrm{KNO}_{3}$ at $15 \mathrm{mM}$, the proline contents of PR, MR, and DR were greater than the control plants. DR leaves demonstrated an increased level of proline content $(14 \%)$ in response to $\mathrm{KNO}_{3}$ during water stress conditions (Fig. $5 \mathrm{~d}$ ). The proline content of all three traits 

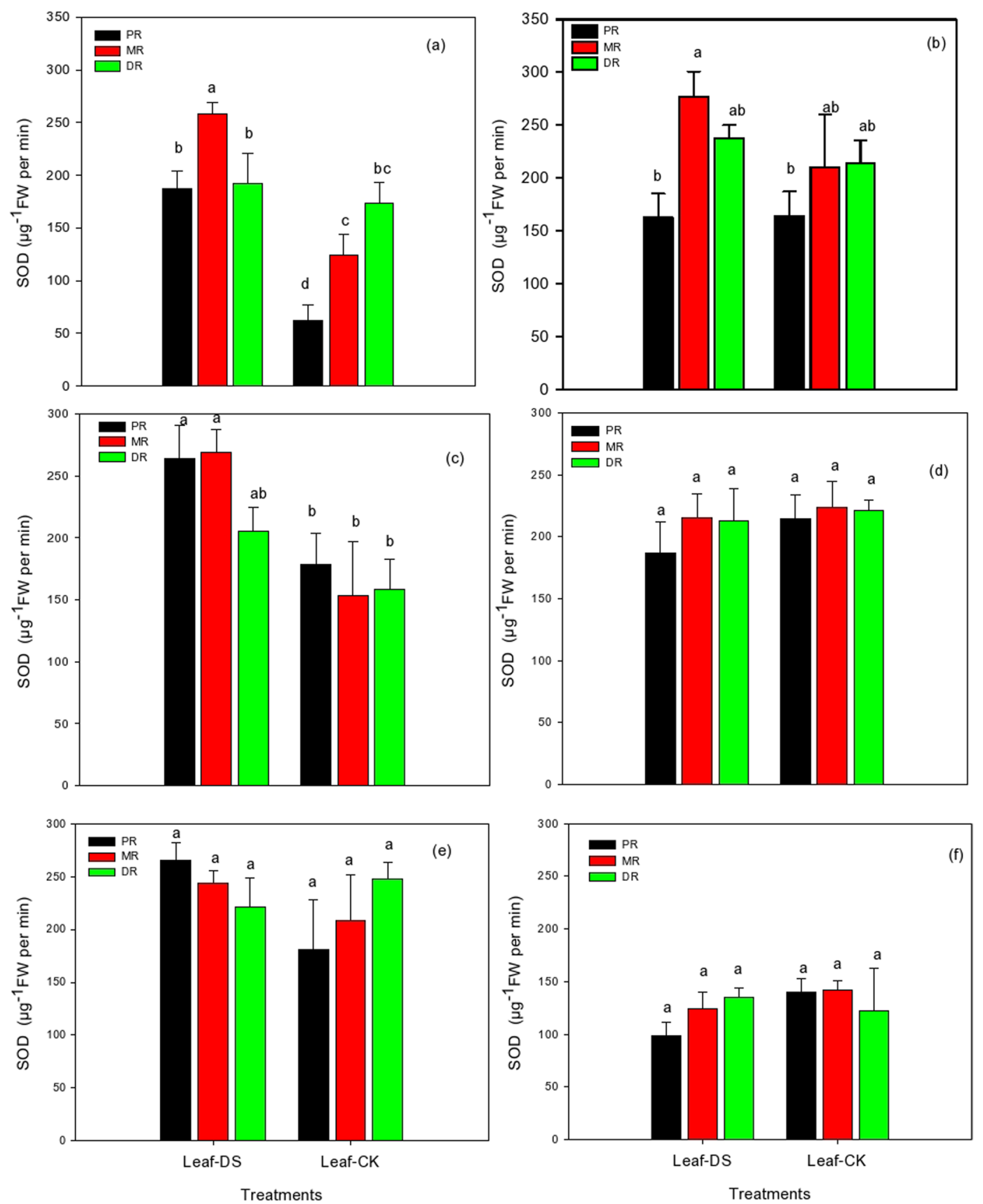

Figure 3. SOD activity in the clonal ramets of Kentucky bluegrass as affected by drought stress under three nitrogen isotopes at low, moderate and high rates. (a) ${ }^{15} \mathrm{NH}_{4} \mathrm{Cl}$ at $1.5 \mathrm{mM},(\mathbf{b}) \mathrm{K}^{15} \mathrm{NO}_{3}$ at $1.5 \mathrm{mM},(\mathbf{c}){ }^{15} \mathrm{NH}_{4} \mathrm{Cl}$ at $15 \mathrm{mM}$, (d) $\mathrm{K}^{15} \mathrm{NO}_{3}$ at $15 \mathrm{mM}$, (e) ${ }^{15} \mathrm{NH}_{4} \mathrm{Cl}$ at $30 \mathrm{mM}$, and (f) $\mathrm{K}^{15} \mathrm{NO}_{3}$ at $30 \mathrm{mM}$.

was significantly enhanced with higher levels of the nitrogenous treatments of $\mathrm{NH}_{4} \mathrm{Cl}$ and $\mathrm{KNO}_{3}$ at $30 \mathrm{mM}$ under drought stress conditions. More proline was synthesized in $\mathrm{MR}$ leaves (49\%) in $\mathrm{NH}_{4} \mathrm{Cl}$, followed by $\mathrm{PR}(39 \%)$ in the $\mathrm{KNO}_{3}$ treatments. On the other hand, $\mathrm{PR}(24 \%)$ in $\mathrm{NH}_{4} \mathrm{Cl}$ and $\mathrm{DR}(10 \%)$ in $\mathrm{KNO}_{3}$ were the least influenced by fertilization treatments with the induction of drought conditions (Fig. 5e,f).

Changes in root and leaf nitrogen isotope abundance in the clonal ramets of Kentucky bluegrass under different nitrogen tracers and water supplies. The nitrogen isotopes in both the roots and leaves of Kentucky bluegrass were significantly influenced by both fertilization treatments upon exposure to drought stress (Fig. 6). An application of $\mathrm{NH}_{4} \mathrm{Cl}$ and $\mathrm{KNO}_{3}$ at $1.5 \mathrm{mM}$ was effective in enhancing the nitrogen isotopes in all three attributes. In the roots and leaves, PR demonstrated an increased level of nitrogen isotopes (35\% and $55 \%$, respectively) in response to $\mathrm{NH}_{4} \mathrm{Cl}$, while with the $\mathrm{KNO}_{3}$ treatment, $\mathrm{MR}$ recorded a greater amount ( $33 \%$ and $12 \%$, respectively) under water stress (Fig. 6a,b). An application of $\mathrm{KNO}_{3}$ at $1.5 \mathrm{mM}$ decreased the nitrogen isotopes in PR roots up to $23 \%$, while in the leaves of PR and DR, nitrogen isotopes were reduced up 

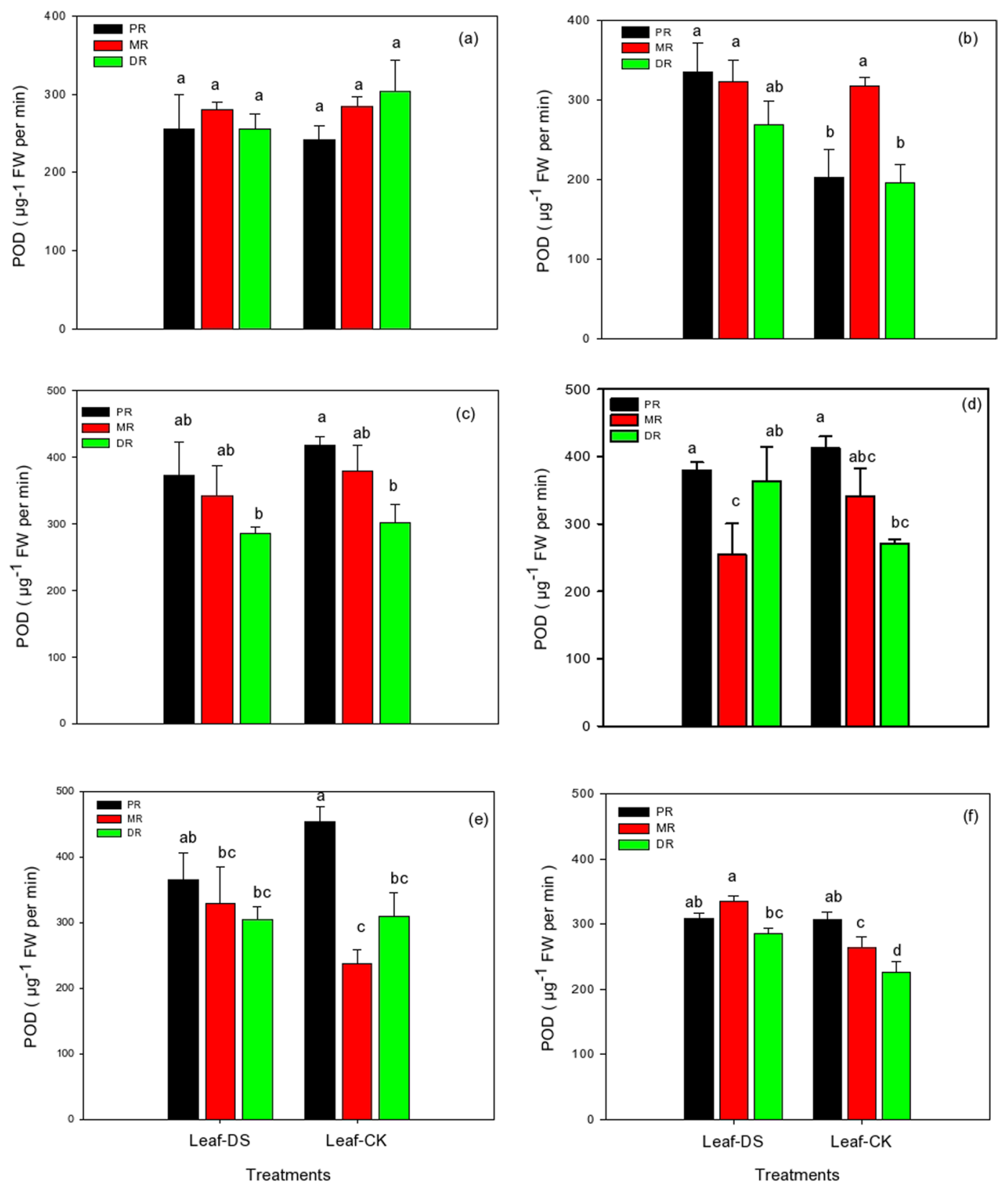

Figure 4. POD activity in the clonal ramets of Kentucky bluegrass as affected by drought stress under three nitrogen isotopes at low, moderate and high rates. (a) ${ }^{15} \mathrm{NH}_{4} \mathrm{Cl}$ at $1.5 \mathrm{mM},(\mathbf{b}) \mathrm{K}^{15} \mathrm{NO}_{3}$ at $1.5 \mathrm{mM},(\mathbf{c}){ }^{15} \mathrm{NH}_{4} \mathrm{Cl}$ at $15 \mathrm{mM},(\mathbf{d}) \mathrm{K}^{15} \mathrm{NO}_{3}$ at $15 \mathrm{mM},(\mathbf{e}){ }^{15} \mathrm{NH}_{4} \mathrm{Cl}$ at $30 \mathrm{mM}$, and (f) $\mathrm{K}^{15} \mathrm{NO}_{3}$ at $30 \mathrm{mM}$.

to the level of $67 \%$ and $40 \%$, respectively. Compared to the control, an application at a moderate level of $\mathrm{NH}_{4} \mathrm{Cl}$ at $15 \mathrm{mM}$ decreased nitrogen isotopes in $\mathrm{PR}$ and $\mathrm{MR}$ roots (17\% and $32 \%$, respectively), while in the leaves of MR and DR, nitrogen isotopes were reduced up to $42 \%$ and $12 \%$, respectively, as shown in Fig. $6 \mathrm{c}$. On the other hand, $\mathrm{KNO}_{3}$ at $15 \mathrm{mM}$ was more effective in increasing ( $6 \%$ and $\left.9 \%\right)$ the isotopes in the roots and leaves of MR. However, the isotope abundance in both the roots and leaves of PR and DR decreased (20\% and 55\%) and (8\% and $16 \%$ ) in response to $\mathrm{KNO}_{3}$ at $15 \mathrm{mM}$ under drought stress, respectively (Fig. 6d). Nitrogen isotope abundance in the roots and leaves in all three traits were significantly influenced by the higher fertilization treatment of both $\mathrm{NH}_{4} \mathrm{Cl}$ and $\mathrm{KNO}_{3}$ at $30 \mathrm{mM}$ under water stress conditions (Fig. 6e,f). Among the three traits, DR roots showed increased (36\%) isotope abundance with $\mathrm{NH}_{4} \mathrm{Cl}$ at $30 \mathrm{mM}$, followed by $\mathrm{MR}(44 \%)$ and then PR (17\%), while PR and MR leaves recorded an enhancement of $50 \%$ and $40 \%$ compared to the control, respectively. Applying $\mathrm{KNO}_{3}$ at $30 \mathrm{mM}$ to plants during drought resulted in the increase of isotope abundance in the roots of all three attributes and only in DR leaves. PR and MR leaves had a reduction ( $81 \%$ and $58 \%$, respectively) in isotope abundance during drought stress when $\mathrm{KNO}_{3}$ was applied at the rate of $30 \mathrm{mM}$ to Kentucky bluegrass plants. 

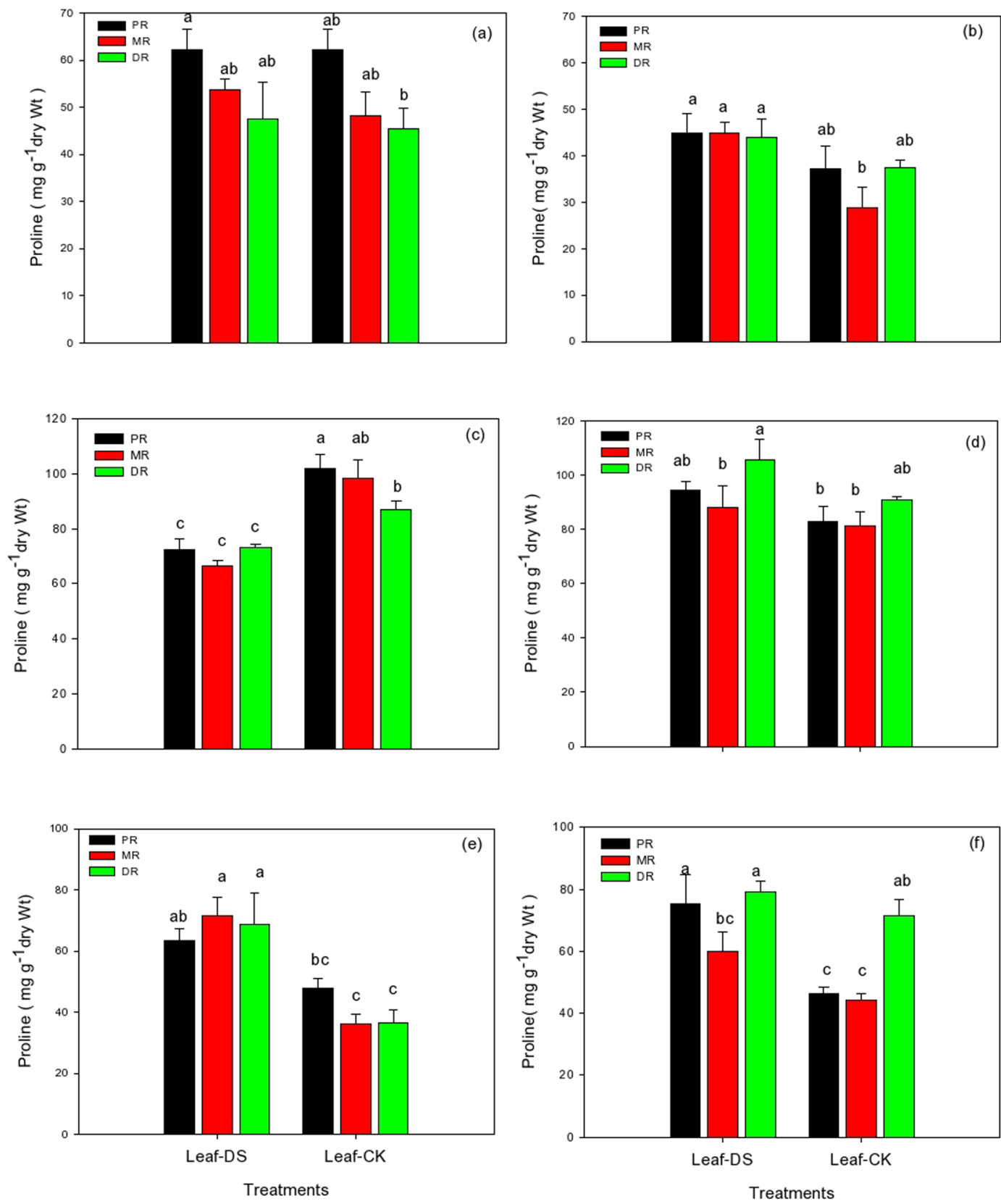

Figure 5. Proline contents in the clonal ramets of Kentucky bluegrass as affected by drought stress under three nitrogen isotopes at low, moderate and high rates. (a) ${ }^{15} \mathrm{NH}_{4} \mathrm{Cl}$ at $1.5 \mathrm{mM},(\mathbf{b}) \mathrm{K}^{15} \mathrm{NO}_{3}$ at $1.5 \mathrm{mM},(\mathbf{c}){ }^{15} \mathrm{NH}_{4} \mathrm{Cl}_{\text {at }}$ $15 \mathrm{mM},(\mathbf{d}) \mathrm{K}^{15} \mathrm{NO}_{3}$ at $15 \mathrm{mM}$, (e) ${ }^{15} \mathrm{NH}_{4} \mathrm{Cl}$ at $30 \mathrm{mM}$, and (f) $\mathrm{K}^{15} \mathrm{NO}_{3}$ at $30 \mathrm{mM}$.

Changes in root and leaf nitrogen content (\%) in the clonal ramets of Kentucky bluegrass under different nitrogen tracers and water supplies. Upon exposure to nitrogenous fertilization under drought stress, the nitrogen content of PR, MR, and DR roots and leaves assuaged the adverse effects of water stress (Fig. 7). Maximum nitrogen content was observed in the roots of all three attributes under well-watered conditions compared to $\mathrm{NH}_{4} \mathrm{Cl}$ and $\mathrm{KNO}_{3}$ fertilization at $1.5 \mathrm{mM}$, and the maximum nitrogen content was observed in MR roots with the $\mathrm{NH}_{4} \mathrm{Cl}$ application between the $\mathrm{NH}_{4} \mathrm{Cl}$ and $\mathrm{KNO}_{3}$ treatments at $1.5 \mathrm{mM}$ under drought stress conditions. A maximum reduction (35\%) was recorded in PR roots, followed by DR (31\%), in response to the $\mathrm{NH}_{4} \mathrm{Cl}$ treatment (Fig. 7a). However, $\mathrm{NH}_{4} \mathrm{Cl}$ fertilization at $1.5 \mathrm{mM}$ significantly improved the nitrogen content of leaves. A maximum increase was recorded in PR (27\%) and then in MR (13\%), while the DR trait was increased only $6 \%$ under stress conditions. An application of $\mathrm{KNO}_{3}$ at $1.5 \mathrm{mM}$ decreased nitrogen content in the roots of all three traits; however, this reduction was most pronounced in MR (60\%), then PR (54\%) and lastly DR (11\%) relative to control conditions (Fig. 7b). On the other side, the $\mathrm{KNO}_{3}$ treatment increased the nitrogen content in the leaves of Kentucky bluegrass. A maximum increase (16\%) was recorded in DR leaves, while the nitrogen content in MR leaves was not significantly affected by $\mathrm{KNO}_{3}$ fertilization. Maximum nitrogen content (28\%) in DR roots was recorded with an application of $\mathrm{NH}_{4} \mathrm{Cl}$ at $15 \mathrm{mM}$; nevertheless, the level 

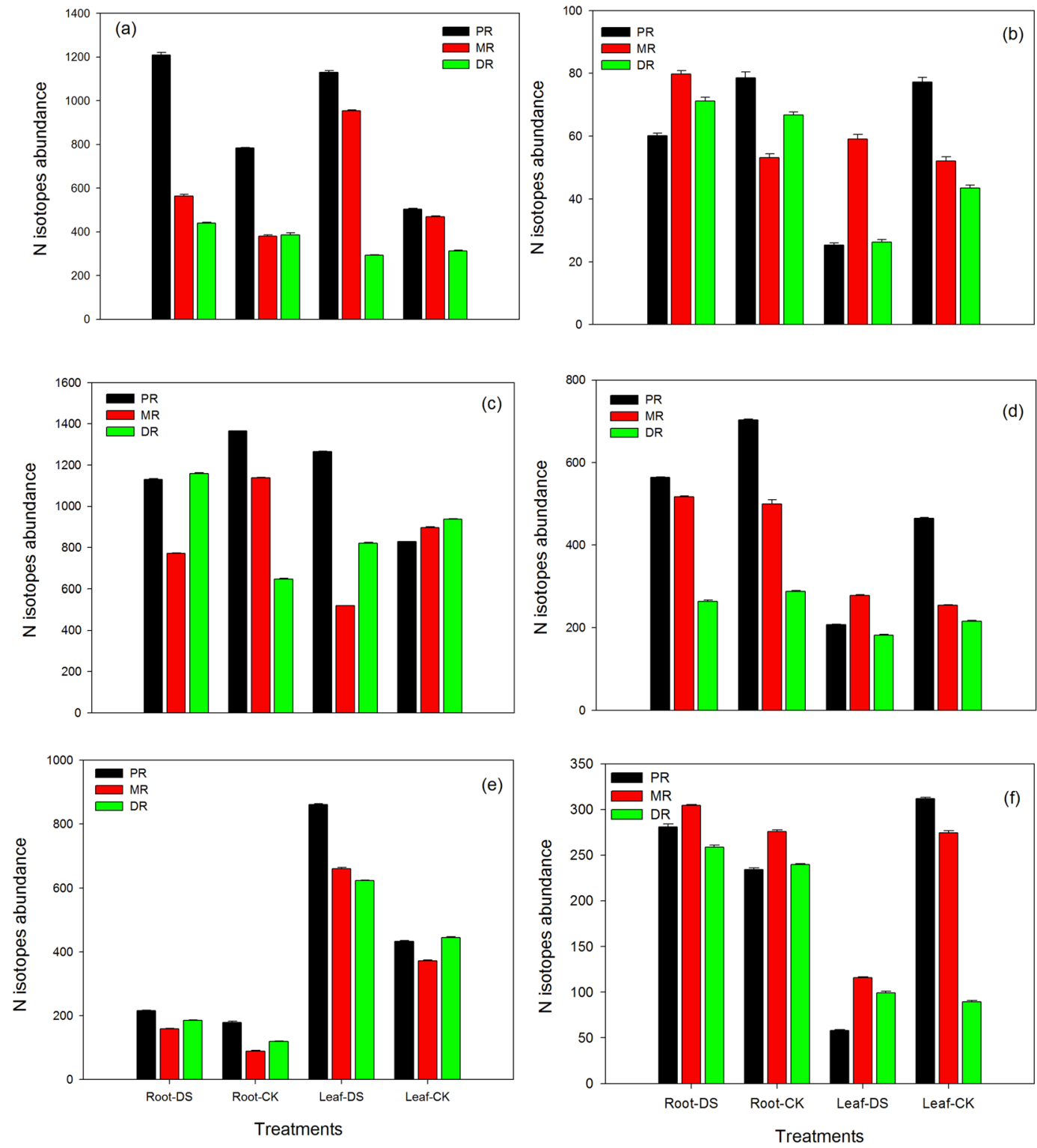

Figure 6. Nitrogen isotopes abundance in the roots and leaves of the clonal ramets of Kentucky bluegrass as affected by drought stress under three nitrogen isotopes at low, moderate and high rates. $(\mathbf{a}){ }^{15} \mathrm{NH}_{4} \mathrm{Cl}$ at $1.5 \mathrm{mM}$, (b) $\mathrm{K}^{15} \mathrm{NO}_{3}$ at $1.5 \mathrm{mM},(\mathbf{c}){ }^{15} \mathrm{NH}_{4} \mathrm{Cl}$ at $15 \mathrm{mM},(\mathbf{d}) \mathrm{K}^{15} \mathrm{NO}_{3}$ at $15 \mathrm{mM},(\mathbf{e}){ }^{15} \mathrm{NH}_{4} \mathrm{Cl}$ at $30 \mathrm{mM}$, and (f) $\mathrm{K}^{15} \mathrm{NO}_{3}$ at $30 \mathrm{mM}$.

of nitrogen content decreased in $\mathrm{PR}(16 \%)$ and $\mathrm{MR}(37 \%)$ under stress conditions. The fertilization of $\mathrm{NH}_{4} \mathrm{Cl}$ remained beneficial, and $\mathrm{NH}_{4} \mathrm{Cl}$ at $15 \mathrm{mM}$ recorded $8 \%, 28 \%$ and $35 \%$ in the nitrogen content of $\mathrm{PR}, \mathrm{MR}$ and $\mathrm{DR}$, respectively (Fig. 7c). Nitrogen content significantly increased in both the roots and leaves of bluegrass plants grown in stressful conditions with a $\mathrm{KNO}_{3}$ application at $15 \mathrm{mM}$. A maximum nitrogen content was recorded in both the roots and leaves ( $37 \%$ and $29 \%$, respectively) of PR, while the MR trait showed the lowest ( $2 \%$ and $4 \%$, respectively) content (Fig. 7d). The application of a high level of $\mathrm{NH}_{4} \mathrm{Cl}$ at $30 \mathrm{mM}$ did not increase the nitrogen content in the roots of PR and DR, while only a $2 \%$ enhancement was recorded in MR roots. There was a maximum reduction of $40 \%$ in DR roots, while only a $22 \%$ reduction was observed in $\mathrm{PR}$ in response to the $\mathrm{NH}_{4} \mathrm{Cl}$ treatment. An application of $\mathrm{NH}_{4} \mathrm{Cl}$ fertilization remained beneficial in the leaves, as this treatment enhanced the nitrogen content of all three traits. The DR leaves demonstrated a maximum nitrogen content (15\%), followed by MR (10\%) and PR (9\%), compared to the control (Fig. 7e). The root contents of PR and DR showed a decrease in nitrogen content in response to $\mathrm{KNO}_{3}$ at $30 \mathrm{mM}$; however, $\mathrm{MR}$ roots demonstrated a positive response to the fertilization treatment. In response to $\mathrm{KNO}_{3}$ at $30 \mathrm{mM}$, a maximum reduction of $40 \%$ in DR roots and a $10 \%$ enhancement in MR were recorded under drought conditions. On the other hand, the leaves of all traits recorded a maximum amount of nitrogen content in the stressed environment. MR leaves (38\%) showed the highest nitrogen content, followed by DR (31\%) and PR (28\%), relative to the control (Fig. 7f). 

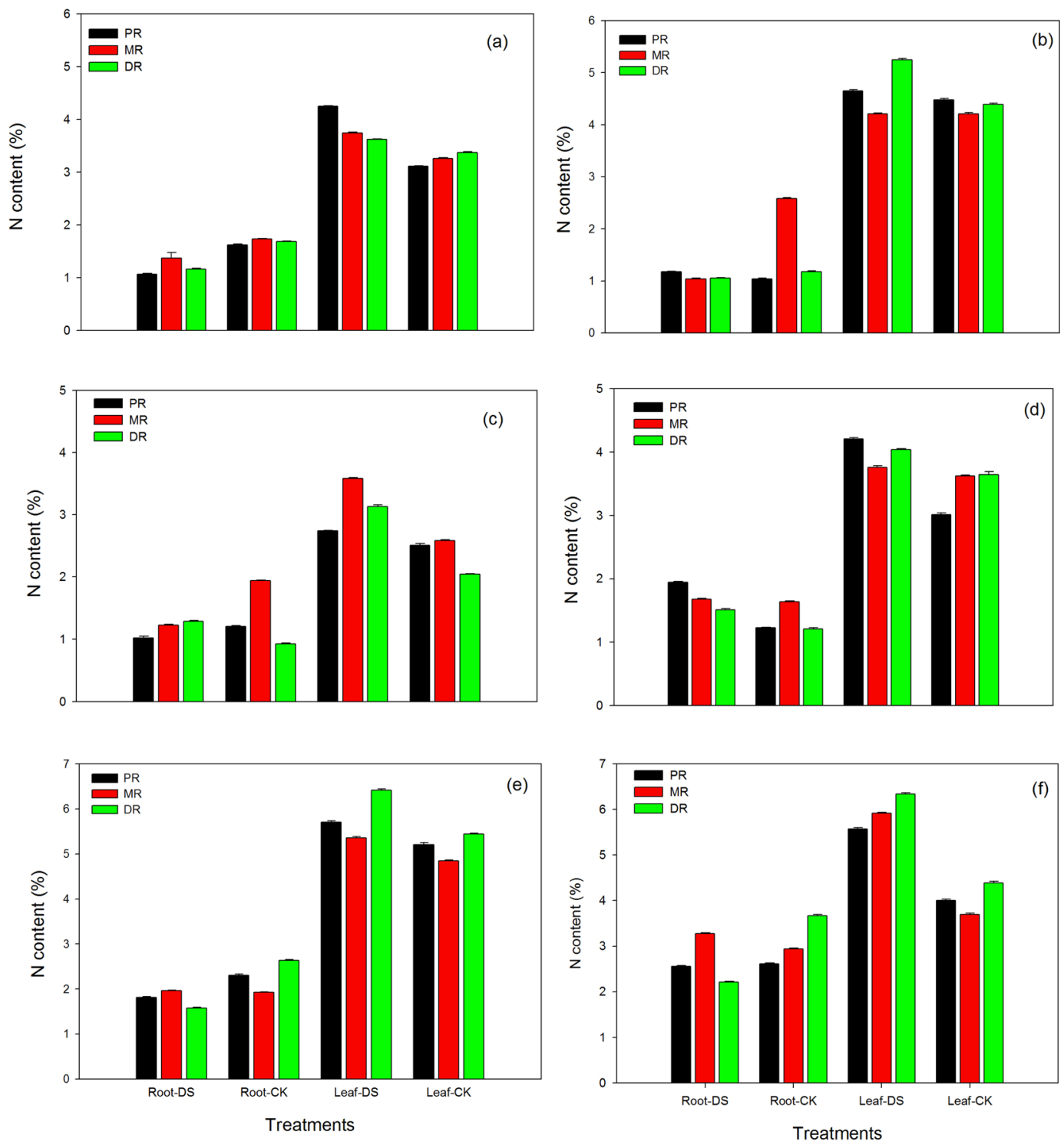

Figure 7. Nitrogen content in the roots and leaves of the clonal ramets of Kentucky bluegrass as affected by drought stress under three nitrogen isotopes at low, moderate and high rates. (a) ${ }^{15} \mathrm{NH}_{4} \mathrm{Cl}$ at $1.5 \mathrm{mM}$, (b) $\mathrm{K}^{15} \mathrm{NO}_{3}$ at $1.5 \mathrm{mM},(\mathbf{c}){ }^{15} \mathrm{NH}_{4} \mathrm{Cl}$ at $15 \mathrm{mM},(\mathbf{d}) \mathrm{K}^{15} \mathrm{NO}_{3}$ at $15 \mathrm{mM},\left(\right.$ e) ${ }^{15} \mathrm{NH}_{4} \mathrm{Cl}$ at $30 \mathrm{mM}$, and (f) $\mathrm{K}^{15} \mathrm{NO}_{3}$ at $30 \mathrm{mM}$.

Changes in relative water content (\%) in the roots and leaf of the clonal ramets of Kentucky bluegrass under different nitrogen tracers and water supplies. We observed that the leaf water content of all three traits in response to nitrogenous fertilizer treatments were significantly influenced by drought stress. Maximum leaf water content was observed in both the roots and leaves of all three traits grown in well-watered conditions (Fig. 8). Under stress conditions, a 22\%, 14\% and 19\% reduction was observed in PR, MR and $\mathrm{DR}$ roots, respectively, in response to $\mathrm{NH}_{4} \mathrm{Cl}$ at $1.5 \mathrm{mM}$. Among the control plants, DR roots showed higher amounts of water content than MR and PR. Similarly, the leaves of stress grown plants had lower water contents than the control. There was a maximum reduction of $4 \%$ in PR leaves, followed by MR (3\%), in response to the $\mathrm{NH}_{4} \mathrm{Cl}$ treatment. However, water content increased only $0.12 \%$ in DR leaves, as shown in Fig. 8 a. The water content of both the roots and leaves of PR, MR and DR decreased in stress conditions under $\mathrm{KNO}_{3}$ at $1.5 \mathrm{mM}$ relative to the control treatment. With the application of $\mathrm{KNO}_{3}$ in drought, a maximum reduction of $35 \%, 23 \%$ and $34 \%$ was recorded in PR, MR and DR, respectively. However, in leaf, a minimum reduction of water content was noted compared to the roots. A maximum reduction of $8 \%$ was observed in both PR and DR, while in MR, the water content was similar to the control (Fig. 8b). The data in Fig. 8c indicated that the water contents of MR roots $(27 \%)$ decreased while DR $(20 \%)$ was the least affected by the application of $\mathrm{NH}_{4} \mathrm{Cl}$ at $15 \mathrm{mM}$. However, water contents in the leaves declined in stress conditions but not abruptly in the roots. A reduction in the range of $15-16 \%$ was noted in the leaves of all three traits of Kentucky bluegrass with $\mathrm{NH}_{4} \mathrm{Cl}$ applications. The fertilization of $\mathrm{KNO}_{3}$ at a moderate level of $15 \mathrm{mM}$ recorded a reduction range of 24 to $27 \%$ and 18 to $24 \%$ in the roots and leaves, respectively, in the PR, MR, and DR traits. Under stress conditions, a maximum reduction was recorded 

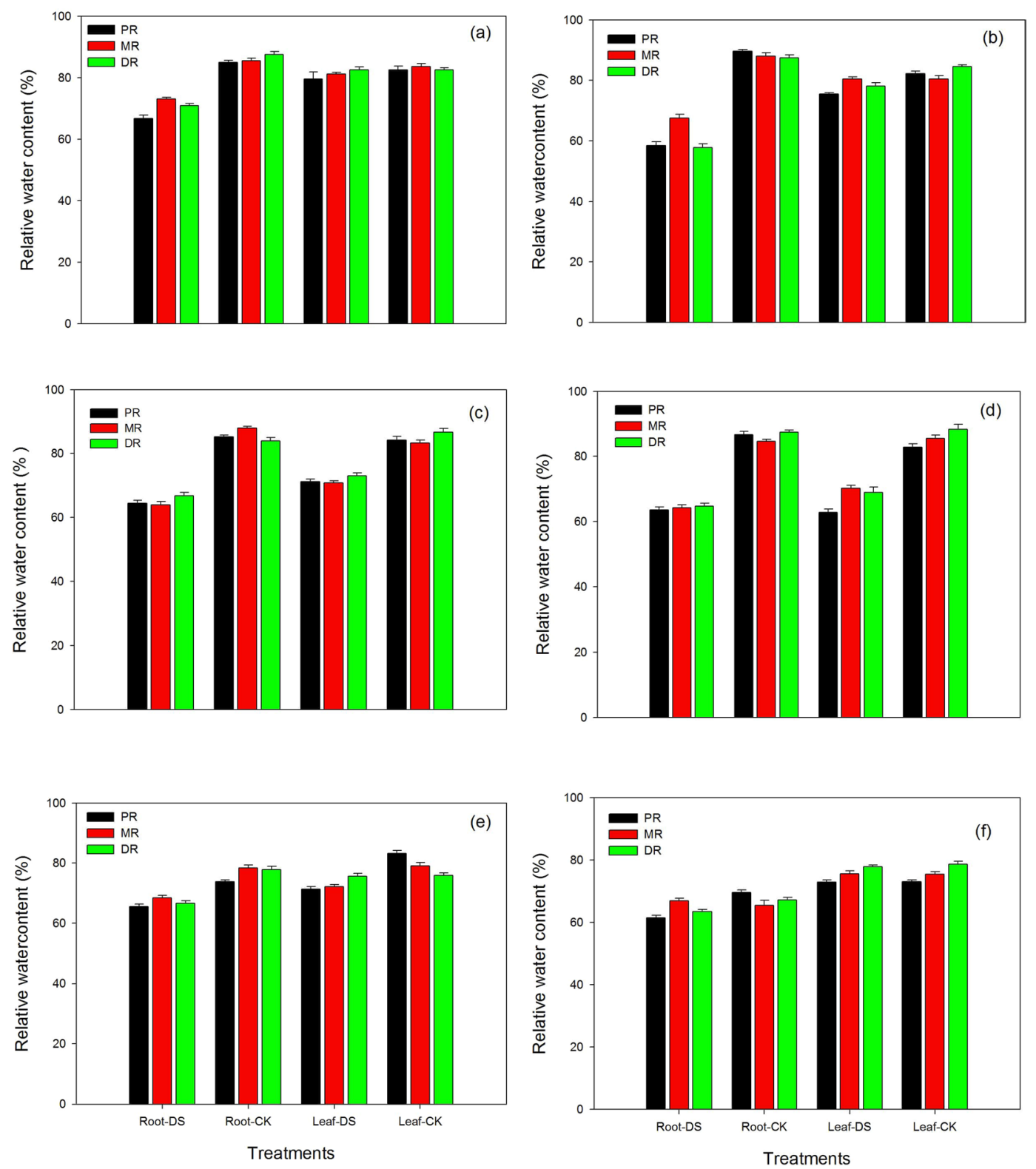

Figure 8. Relative water content in the roots and leaves of the clonal ramets of Kentucky bluegrass as affected by drought stress under three nitrogen isotopes at low, moderate and high rates. (a) ${ }^{15} \mathrm{NH}_{4} \mathrm{Cl}$ at $1.5 \mathrm{mM}$, (b) $\mathrm{K}^{15} \mathrm{NO}_{3}$ at $1.5 \mathrm{mM},(\mathbf{c}){ }^{15} \mathrm{NH}_{4} \mathrm{Cl}$ at $15 \mathrm{mM},(\mathbf{d}) \mathrm{K}^{15} \mathrm{NO}_{3}$ at $15 \mathrm{mM},(\mathbf{e}){ }^{15} \mathrm{NH}_{4} \mathrm{Cl}$ at $30 \mathrm{mM}$, and (f) $\mathrm{K}^{15} \mathrm{NO}_{3}$ at $30 \mathrm{mM}$.

in both the roots and leaves of PR plants, as shown in Fig. $8 \mathrm{~d}$. At $30 \mathrm{mM}$, the $\mathrm{NH}_{4} \mathrm{Cl}$ application exhibited an 11 to $14 \%$ and 0.5 to $14 \%$ decline in water content compared to the control. Furthermore, there was a maximum reduction in DR roots and PR leaves in response to $\mathrm{NH}_{4} \mathrm{Cl}$ under drought conditions (Fig. 8e). The water contents of both roots and roots were also considerably decreased in Kentucky bluegrass with an application of $\mathrm{KNO}_{3}$ at $30 \mathrm{mM}$ and upon the exposure of drought stress. A reduction of 0.4 to $11 \%$ and 0.1 to $1 \%$ in the roots and leaves, respectively, of PR, MR and DR traits were noted under stress conditions (Fig. 8f).

Changes in water potential (-Mpa) in the roots and leaf of the clonal ramets of Kentucky bluegrass under different nitrogen tracers and water supplies. The fertilization treatment under drought stress conditions consistently and significantly $(\mathrm{P} \leq 0.05)$ reduced root and leaf water potential in $P R, M R$ and DR traits in comparison to the controls of Kentucky bluegrass (Fig. 9). Among the traits we examined, drought stress decreased the root water potential of all three traits in the range of 20 to $41 \%$ under $\mathrm{NH}_{4} \mathrm{Cl}$ at $1.5 \mathrm{mM}$. The water potential of DR roots was severely influenced by stress conditions, followed by MR, compared to the control treatments. Nonetheless, the trend of declination in water potential was also recorded in the leaves of Kentucky bluegrass. A significant reduction of $36 \%, 32 \%$ and $37 \%$ in PR, MR and DR leaves, respectively, was noted at $1.5 \mathrm{mM}$ of the $\mathrm{NH}_{4} \mathrm{Cl}$ application, as shown in Fig. 9a. The DR leaves showed the maximum amount of water potential among the control treatments. Next, we addressed the influence of progressive drought and 

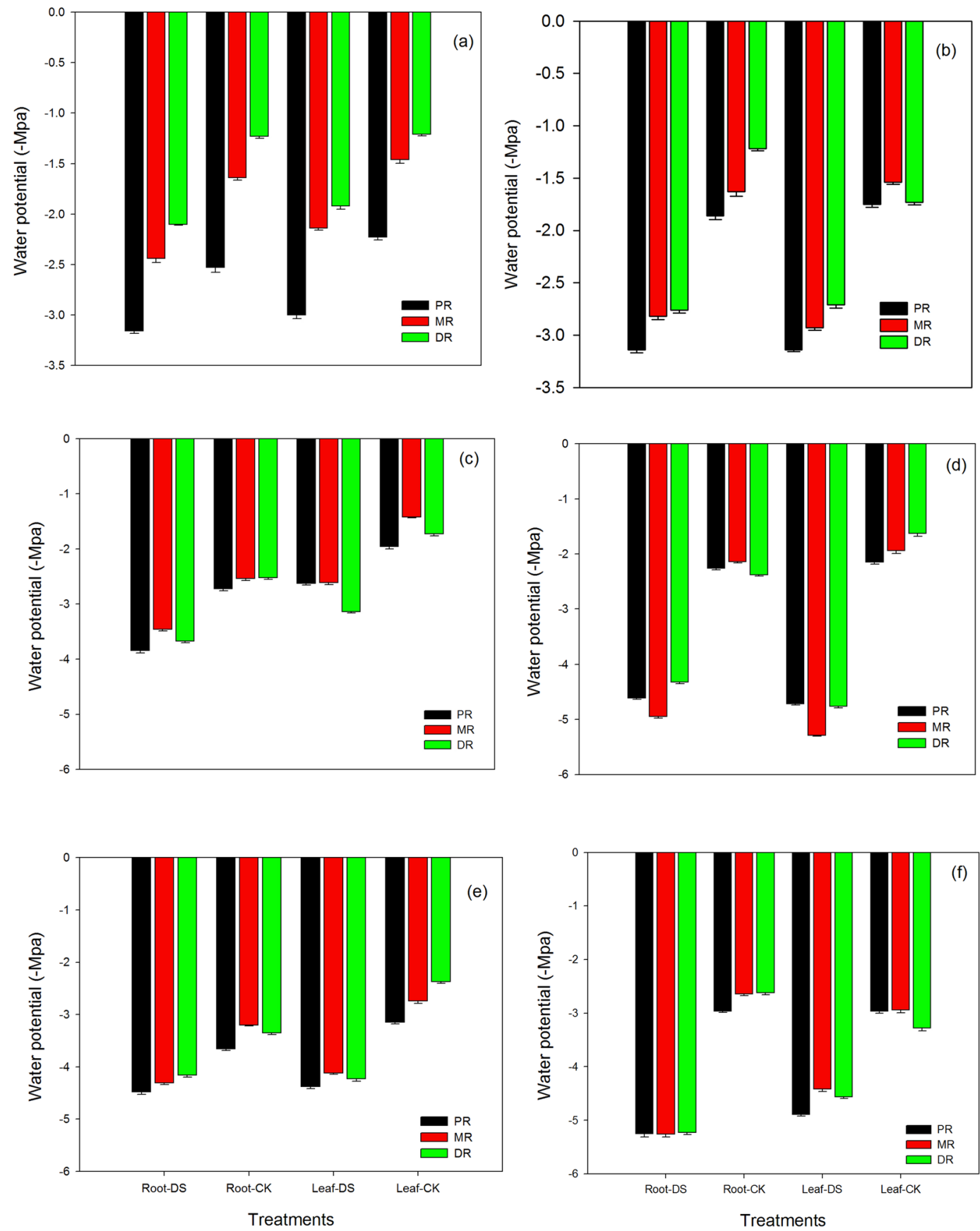

Figure 9. Water potential in the roots and leaves of the clonal ramets of Kentucky bluegrass as affected by drought stress under three nitrogen isotopes at low, moderate and high rates. (a) ${ }^{15} \mathrm{NH}_{4} \mathrm{Cl}$ at $1.5 \mathrm{mM}$, (b) $\mathrm{K}^{15} \mathrm{NO}_{3}$ at $1.5 \mathrm{mM},(\mathbf{c}){ }^{15} \mathrm{NH}_{4} \mathrm{Cl}$ at $15 \mathrm{mM},(\mathbf{d}) \mathrm{K}^{15} \mathrm{NO}_{3}$ at $15 \mathrm{mM},(\mathbf{e}){ }^{15} \mathrm{NH}_{4} \mathrm{Cl}$ at $30 \mathrm{mM}$, and (f) $\mathrm{K}^{15} \mathrm{NO}_{3}$ at $30 \mathrm{mM}$.

$\mathrm{KNO}_{3}$ at $1.5 \mathrm{mM}$ on the roots and leaves of all three attributes. The water potential of both the roots and leaves in all traits were mostly suppressed by prolonged water stress at $1.5 \mathrm{mM}$ of the $\mathrm{KNO}_{3}$ application. Therefore, 41 to $56 \%$ and 36 to $47 \%$ reductions in the water potential of the roots and leaves, respectively, were recorded in PR, MR and DR of Kentucky bluegrass. DR roots and MR leaves exhibited maximum water potential in the control plants compared to the rest of the treatments (Fig. 9b). Applying $\mathrm{NH}_{4} \mathrm{Cl}$ at $15 \mathrm{mM}$ to drought plants resulted in decreased water potential of both the roots and leaves of all three traits of Kentucky bluegrass. At $15 \mathrm{mM}^{\circ} \mathrm{NH}_{4} \mathrm{Cl}$ fertilization in drought conditions, a considerable decline in the range of $27-31 \%$ and $25-46 \%$ was recorded in the roots and leaves, respectively, of PR, MR and DR compared to the control plants. However, the data pertaining to water potential (Fig. 9c) indicated that DR roots and MR leaves of the control plants showed maximum potential. The same trend was also observed with a moderate application of $\mathrm{KNO}_{3}$ treatment at $15 \mathrm{mM}$ under water stress conditions; however, the reduction was more severe than with $\mathrm{NH}_{4} \mathrm{Cl}$ fertilization. It was noted that there was a 45 to $57 \%$ and 54 to $66 \%$ reduction in the water potential of the roots and leaves, respectively, of all 
three attributes under a $\mathrm{KNO}_{3}$ application at a moderate rate (Fig. 9d). Likewise, the water potential of roots and leaves declined by 18 to $26 \%$ and 28 to $44 \%$, respectively, in response to a high level of $\mathrm{NH}_{4} \mathrm{Cl}$ at $30 \mathrm{mM}$ under drought conditions. However, MR roots and DR leaves recorded maximum water potential among all attributes of the control treatment (Fig. 9e). In $\mathrm{KNO}_{3}$ fertilization at $30 \mathrm{mM}$, the water potential of all the three traits was drastically decreased in comparison with the $\mathrm{NH}_{4} \mathrm{Cl}$ application. A substantial reduction of 44 to $50 \%$ and 28 to $39 \%$ under $\mathrm{KNO}_{3}$ fertilization was recorded in the roots and leaves of $\mathrm{PR}, \mathrm{MR}$ and DR traits grown in stressful conditions. Among all attributes under drought conditions, the water potential of PR roots and leaves was significantly affected, as shown in Fig. 9f.

\section{Discussion}

The physiological integration is one of the physiology characteristics and one of the important mechanisms in the growth, development and adaptation of clonal plants. Resources translocate or redistribute among ramets increases clonal growth and enhance the ability to adapt adverse environments. The present study assessed three ramet types of Kentucky bluegrass for their physiological and biochemical responses to nitrogen isotopes labelled ${ }^{15} \mathrm{NH}_{4} \mathrm{Cl}$ and $\mathrm{K}^{15} \mathrm{NO}_{3}$ under prolonged drought conditions. Under a drought stress environment, nutrient absorption and water uptake are reduced, which led to decreased morphological, physiological and biochemical attributes of the plants. Consequently, plant performance was influenced ${ }^{39}$. Under $\mathrm{N}$ nutrition, there was an improvement in the SOD, POD, and catalase activity systems in the water-stressed plants, which could be the strategy for enhancing the drought resistance ability. In this study, $\mathrm{N}$ could have contributed to the defence of photosynthetic organs, and these findings are consistent with Saneoka et al. ${ }^{40}$ who recommended that $\mathrm{N}$ nutrition played a pivotal role in the drought tolerance of bentgrass by stopping cell membrane damage and enhancing osmoregulation (Figs. 2-4). In plants, a variety of antioxidant enzymes, lipids and water soluble molecules play vital roles in scavenging reactive oxygen species. Of these, antioxidant enzymes are considered the most effectual in reducing oxidative damage $\mathrm{e}^{7,41,42}$. The results depicted that an application of nitrogenous fertilizer improved the drought tolerance in all three ramet types due to enhanced the functions of cellular antioxidants detoxification and osmoprotection, which were taken as the main indicators of stress tolerance (Figs. 2-4). $\mathrm{NH}_{4} \mathrm{Cl}$ and $\mathrm{KNO}_{3}$ tracers could enhance the performance of protective enzymes as observed in our study, and these antioxidant enzymes could alleviate the harmful influence of ROS (reactive oxygen species) on plants and retained a balance between their production and their removal during stressful conditions ${ }^{7}$ In the present study, increased levels of antioxidant activities with nitrogen isotope applications helped the three ramets of Kentucky bluegrass overcome injuries to the tissues and decreased cellular toxic levels produced under prolonged water stress environments. Basu et al. ${ }^{43}$ also observed that indica rice (Oryza sativa indica) tolerance to drought stress was associated with the enhanced capability of antioxidant enzymes to decrease the negative effects induced by drought stress. However, there was generally difference observed between the integration of SOD, POD and CAT in PR, MR and DR of Kentucky bluegrass, which confirmed the physiological integration did exist in SOD, POD and CAT activities between ramets, and in most cases, the MR performed more active than PR and DR indicated that MR take more responsibility to balance the vitality of other ramets under drought conditions.

Proline is considered one of the most significant osmolytes, which assists in promoting water retention and reducing the damaging effects of water stress in plants ${ }^{44}$. During adverse environmental conditions, it deposits quickly and more frequently as compare to any other amino $\mathrm{acid}^{45}$. It could play a vital role in stress-resistance mechanisms by performing as an osmoprotectant, assisting osmoregulation, the stabilization of protein-synthesis machinery, and the regulation of cytosolic acidity ${ }^{46}$. We observed increased levels of proline in all three ramet traits under drought stress in response to nitrogenous fertilizer (Fig. 5); however, this enhancement was less pronounced in control plants and could be due to increased cytosolic concentrations of osmolytes in drought conditions, which not only assist in maintaining the tissues but also takes part in osmoregulation ${ }^{7,47}$.

The accumulation of $\mathrm{N}$ isotope abundances increased with the application of $\mathrm{NH}_{4} \mathrm{Cl}$ in both the roots and leaves however, $\mathrm{KNO}_{3}$ only enhanced it in root portion of all three ramets, which facilitated plants to perform better during drought stress (Fig. 6). Yoneyama et al. ${ }^{33}$ reported that the $\delta^{15} \mathrm{~N}$ values in the xylem and plant tissues are associated with acquired $\mathrm{N}$, and the value can be altered by $\mathrm{N}$ metabolism. Our results also indicated that drought stress conditions inhibited nitrogen fixation and could be due to the fact that nitrogenase is more sensitive than nitrate reductase. In the present study, application of $\mathrm{NH}_{4} \mathrm{Cl}$ and $\mathrm{KNO}_{3}$ under drought stress enhanced the nitrogen contents more pronouncedly in the leaves of all three ramets compared to control conditions; however, in root portion the augmentation was not so high under drought stress (Fig. 7). The differences in nitrogen content between three ramets along with the nitrogen distribution indicated that the nitrogen were integrated. Nitrogen is a significant constituent of Chl, proteins and Rubisco, which influences plant metabolism during water stress conditions. Grassi and Magnani ${ }^{48}$ suggested that adequate $\mathrm{N}$ increased the resurgence of photosynthetic biochemistry, and its slow recovery was noted in those conditions where plants were exposed to severe drought stress conditions under limited $\mathrm{N}$ supplies. Therefore, better nitrogen nutrition could alleviate the damaging effects of drought stress by sustaining the metabolic activities even at low tissue water potential, as recorded in our study.

Plant-water relations in response to $\mathrm{N}$ nutrition in Kentucky bluegrass roots and leaves were also disturbed under water stress conditions (Figs. 8, 9); however, moderate and high levels of $\mathrm{NH}_{4} \mathrm{Cl}$ and $\mathrm{KNO}_{3}$ improved these relations, so our results recommended that plant-water relations (both relative water content and water potential) may serve as an indicator of plant water status, and three ramets capability to sustain sufficient water status develops water stress adaptability by increasing drought resistance. Relatively, the water content of DR was higher than PR and DR, which indicated that the water was integrated by three ramets and tended to transport to young plants under different nitrogen drought conditions. Under different abiotic stresses, reduced water potential are the major causes of loss in dry matter production and the other attributes of plants ${ }^{49}$. By maintaining water potential, the accretion of compatible osmolytes engaged in osmoregulation allowed supplementary water to be taken up from the environment, thus buffering the instant influence of water scarcity within the organism ${ }^{7,50-52}$. 


\section{Conclusion}

To the best of our knowledge, using the nitrogen isotopes to quantitatively infer the physiological activities responding to nitrogen and drought in Kentucky bluegrass within the clonal ramets has not been addressed before. The present results clearly show that it is effectively using nitrogen isotopes to infer the impact of drought stress and nitrogen on the physiological attributes of Kentucky bluegrass clonal remats. The antioxidant activities and proline contents of the ramets in Kentucky bluegrass were observed to be correlated with N-mediated and physiological integration. The SOD, POD, CAT activities and free proline content in the ramet of MR performed more active than PR and DR indicated that MR take more responsibility to balance the vitality of other ramets under drought conditions. Nitrogen concentration with $30 \mathrm{mM}$ caused significant down-regulation of PpGS2 expression, but it was slightly up-regulated after imposed drought. Plant-water relations in response to nitrogen in Kentucky bluegrass were also integrated by three ramets and tended to transport to young plants under different drought and nitrogen conditions. In addition, nitrogen isotope abundance was enhanced in both the roots and leaves of the three ramets of Kentucky bluegrass with the application of ${ }^{15} \mathrm{NH}_{4} \mathrm{Cl}$, however, $\mathrm{K}^{15} \mathrm{NO}_{3}$ only enhanced in root portion. The nitrogen content was more pronounced in leaves compared to roots under both drought and control conditions. Nitrogen status of Kentucky bluegrass implied that nitrogen assimilation and allocation was integrated with a certain orientation and location characteristics within the remats.

Received: 7 September 2019; Accepted: 5 February 2020;

Published online: 14 April 2020

\section{References}

1. Saxe, H., Ellsworth, D. S. \& Heath, J. Tree and forest functioning in an enriched $\mathrm{CO}_{2}$ atmosphere. New Phytol. 139, 395-436 (1998).

2. UNEP. United Nations Framework Convention on Climate Change Information Kit. Climate change information sheets. (ed. Williams, M.) (UNEP's information unit for conventions, international environment house, Geneva Châtelaine Switzerland, 1999).

3. IPCC. In Climate change 2014: synthesis report. contribution of working groups I, II and III to the fifth assessment report of the intergovernmental panel on climate change. (eds Pachauri, R. K. et al.). 56-73 (Cambridge University Press, 2014).

4. Dai, A. Drought under global warming: a review. Wiley Inter discip. Rev. Clim. Change. 2, 45-65, https://doi.org/10.1002/wcc.81 (2011).

5. Jones, P. \& Thornton, P. The potential impacts of climate change on maize production in Africa and Latin America in 2055. Glob. Environ. Change. 13, 51-59, https://doi.org/10.1016/S0959-3780(02)00090-0 (2003).

6. Ludlow, M. M. Strategies of response to water stress. In: Kreeb, K. H., Richter, H., Hinckley, T. M. ed. Structural and functional responses to environmental stresses. The Netherlands, The Hague, SPB Aca- demic. Pp. 269-281 (1989).

7. Farooq, M., Wahid, A., Kobayashi, N., Fujita, D. \& Basra, S. M. A. (2009c). Plant drought stress: effects, mechanisms and management. Agron Sust Dev. 29, 185-212.

8. Fahad, S. \& Bano, A. Effect of salicylic acid on physiological and biochemical characterization of maize grown in saline area. PakJ Bot. 44, 1433-1438 (2012).

9. Fahad, S. et al. Crop plant hormones and environmental stress. Sustain Agric Rev. 15, 371-400 (2015).

10. Saud, S., Chen, Y., Longm, B., Fahad, S. \& Sadiq, A. The different impact on the growth of cool season turf grass under the various conditions on salinity and draught stress. Int J Agric Sci Res. 3, 77-84 (2013).

11. Saud, S. et al. Silicon application increases drought tolerance of Kentucky bluegrass by improving plant water relations and morpho physiological functions. Sci World J., https://doi.org/10.1155/2014/368694 (2014)

12. Saud, S. et al. Silicate application increases the photosynthesis and its associated metabolic activities in Kentucky bluegrass under drought stress and post-drought recovery. Environ Sci Pollut Res., https://doi.org/10.1007/s11356-016-6957-x (2016)

13. Wang, W., Vinocur, B. \& Altman, A. Plant responses to drought, salinity and extreme temperatures: towards genetic engineering for stress tolerance. Planta. 218, 1-14, https://doi.org/10.1007/s00425-003-1105-5 (2003).

14. Chaves, M. M., Maroco, J. P. \& Pereira, J. S. Understanding plant responses to drought from genes to the whole plant. Funct. Plant Bio. 30, 239-264 (2003).

15. Dong, M. Resources heterogeneity in plant clonal growth. Foraging Plant. 38, 828-835 (1996).

16. Alpert, P., Holzapfel, C. \& Slominski, C. Differences in performance between genotypes of Fragaria chiloensis with different degree of resource sharing. J. Eco. 91, 27-35 (2003).

17. Pitelka, L. F. \& Ashmun, J. W. Physiological and integration of ramets in clonal plants [M]. New Haven: Yale University Press, 399-435 (1985).

18. Eleni, M. A., William, A. M., Stacy, A. B. \& Bingru, H. Differential responses of hybrid bluegrass and Kentucky bluegrass to drought and heat Stress. Hort Sci. 43(7), 2191-2195 (2008).

19. Park, J. H. \& Lee, B. W. Photosynthetic characteristics of rice cultivars with depending on leaf senescence during grain filling. J. Crop Sci. 48, 216-223 (2003).

20. Madani, A., Rad, A. S., Pazoki, A. \& Nourmohammadi, G. Wheat (Triticum aestivum L.) grain filling and dry matter partitioning responses to source: sink modification sunder post anthesis water and nitrogen deficiency. Acta Sci. Agron. 32, 145-151, https://doi. org/10.4025/actasciagron.v32i1.6273 (2010)

21. Mobasser, H. R., Mohammadi, G. N., Heidari, H., Abad, S. \& Rigi, K. Effect of application elements, drought stress and variety on nutrients of grain wheat in Zahak region, Iran. J. Biodivers. Environ. Sci. 5, 105-110 (2014).

22. Liu, S. Dynamics of nitrate fertilizer of Kentucky bluegrass and soil quality [D]. Master thesis. China Agricultural University, Beijing (2004).

23. Tian, T. N.Effects of Nitrogen and Water on sarmentosum growth and turf quality [D]. Master thesis. Nanjing Agricultural University, Nanjing (2009).

24. Teixeira, E. I. et al. The impact of water and nitrogen limitation on maize biomass and resource-use efficiencies for radiation, water and nitrogen. Field Crops Res. 168, 109-118, https://doi.org/10.1016/j.fcr.2014.08.002 (2014).

25. Araus, J. L., Slafer, G. A., Reynolds, M. P. \& Royo, C. Plant breeding and drought in C3 cereals: what should we breed for? Ann.Bot. 89, 925-940, https://doi.org/10.1093/aob/mcf049 (2002).

26. Araus, J. L. et al. Environmental factors determining carbon isotope discrimination and yield in durum wheat under Mediterranean conditions. Crop Sci. 43, 170-180, https://doi.org/10.2135/cropsci2003.1700 (2003).

27. Yousfi, S., Serret, M. D., Voltas, J. \& Araus, J. L. Effect of salinity and water stress during the reproductive stage on growth, ion concentrations, 113C, and $\delta^{15} \mathrm{~N}$ of durum wheat and related amphiploids. J. Exp.Bot. 61, 3529-3542, https://doi.org/10.1093/jxb/ erq184 (2010).

28. Pritchard, E. S. \& Guy, R. D. Nitrogen isotope discrimination in white spruce fed with low concentrations of ammonium and nitrate. Trees Struct. Funct. 19, 89-98, https://doi.org/10.1007/s00468-004-0367-2 (2005). 
29. Yousfi, S., Serret, M. D., Márquez, A. J., Voltas, J. \& Araus, J. L. Combined use of $\delta{ }^{13} \mathrm{C}, \delta{ }^{18} \mathrm{O}$ and $\delta^{15} \mathrm{~N}$ tracks nitrogen metabolism and genotypic adaptation of durum wheat to salinity and water deficit. New Phytol. 194, 230-244, https://doi. org/10.1111/j.1469-8137.2011.04036.x (2012).

30. Robinson, D. et al. Using stable isotope natural abundances $\left(\delta^{15} \mathrm{~N}\right.$ and $\left.\delta^{13} \mathrm{C}\right)$ to integrate the stress responses of wild barley (Hordeum spontaneum C. Koch.) genotypes. J. Exp. Bot. 51, 41-50, https://doi.org/10.1093/jexbot/51.342.41 (2000).

31. Yousfi, S., Serret, M. D. \& Araus, J. L. Shoot $\delta^{15} \mathrm{~N}$ gives a better indication than ion concentration ${ }^{\Delta} 113 \mathrm{C}$ of genotypic differences in the response of durum wheat to salinity. Funct. Plant Biol. 36, 144-155, https://doi.org/10.1071/FP08135 (2009).

32. Peuke, A. D., Gessler, A. \& Rennenberg, H. The effect of drought on C and N stable isotopes in different fractions of leaves, stems and roots of sensitive and tolerant beech ecotypes. Plant Cell Environ. 29, 823-835, https://doi.org/10.1111/j.1365-3040.2005.01452.x (2006).

33. Yoneyama, T., Handley, L. L., Scrimgeour, C. M., Fisher, D. B. \& Raven, J. A. Variations of the natural abundances of nitrogen and carbon isotopes in Triticum aestivum, with special reference to phloem and xylem exudates. New Phytol. 137(205), 213 (1997).

34. Sergio, R. R. \& Rube'n, R. Clonal integration in Fragaria vesca growing in metal-polluted soils: parents face penalties for establishing their offspring in unsuitable environments. Ecol. Res. 27, 95-106, https://doi.org/10.1007/s11284-011-0876-6 (2012).

35. Bai, T. H., Li, C. Y., Ma, F. W., Shu, H. R. \& Han, M. Y. Exogenous salicylic acid alleviates growth inhibition and oxidative stress induced by hypoxia stress in Malus robusta Rehd. J. Plant Growth Regul. 28, 358-366 (2009).

36. Bruggink, E. \& Huang, C. Vessel contents of leaves after excision: a test of the scholander assumption. Am. J. Bot. 84, 1217-1222, https://doi.org/10.2307/2446045 (1997).

37. Gilmour, S. J., Sebolt, A. M., Salazar, M. P., Everard, J. D. \& Thomashow, M. F. Over expression of the Arabidopsis CBF3 transcriptional activator mimics multiple biochemical changes associated with cold acclimation. Plant Physiol. 124, 1854-1865 (2000).

38. SigmaPlot 10.0 (Systat Software, San Jose, CA).

39. Ashraf, M. \& Foolad, M. R. Roles of glycine betaine and proline in improving plant abiotic stress resistance. Environ. Exp. Bot. 59, 206-216 (2007)

40. Saneoka, H., Moghaieb, R. E. A., Premachandra, G. S. \& Fujita, K. Nitrogen nutrition and water stress effects on cell membrane stability and leaf water relations in Agrostis palustris Huds. Environ. Exp. Bot. 52, 131-138, https://doi.org/10.1016/j. envexpbot.2004.01.011 (2004)

41. Halliwell, B. \& Gutteridge, J. M. C. Free Radicals in Biology and Medicine [M]. Oxford University Press, New York (1999).

42. Foyer, C. H. \& Fletcher, J. M. Plant antioxidants: colour me healthy. Biologist. 48, 15-120 (2001).

43. Basu, S., Roychoudhury, A., Saha, P. P. \& Sengupta, D. N. Differential antioxidative response of indica rice cultivars to drought stress. Plant Growth Regul. 60, 51-59 (2010).

44. Serraj, R. \& Sinclair, T. R. Osmolyte accumulation: can it really help increase crop yield under drought conditions? Plant, Cell Environ. 25, 333-341 (2002).

45. Lutts, S., Majerus, V. \& Kinet, J. M. NaCl effect on proline metabolism in rice (oryza Sativa) seedling. Physiol. Plant. 105, 450-458 (1999).

46. Qureshi, M. I., Abdin, M. Z., Qadir, S. \& Iqbal, M. Lead - induced oxidative stress and metabolic alterations in Cassia angustifolia Vahl. Biol. Plant. 51(1), 121-128 (2007).

47. Lea, P. J., Blackwell, R. D., Murray, A. J. S. \& Joy, K. W. The use of mutants lacking glutamine synthetase and glutamate synthase to study their role in plant nitrogen metabolism. In Recent Advances in Phytochemistry. 23, 157-189 (1989).

48. Grassi, G. \& Magnani, F. Stomatal, mesophyll conductance and biochemical limitations to photosynthesis as affected by drought and leaf ontogeny in ash and oak trees. Plant Cell Environ. 28, 834-849, https://doi.org/10.1111/j.1365-3040.2005.01333.x [Cross Ref] (2005).

49. Gepstein, S. \& Glick, B. R. Strategies to ameliorate abiotic stress-induced plant senescence. Plant Mol.Biol. 82, 623-633, https://doi. org/10.1007/s11103-013-0038-z (2013).

50. Kumar, S. G., Mattareddy, A. \& Sudhakar, C. NaCl effects on proline metabolism in two high yielding genotypes of mulberry (Morus alba L.) with contrasting salt tolerance. Plant Sci. 165, 1245-1251 (2003).

51. Farooq, M., Basra, S. M. A., Wahid, A. \& Rehman, H. Exogenously applied nitric oxide enhances the drought tolerance in fine grain aromatic rice (Oryza sativa L.). J. Agron. Crop Sci. 195, 254-261 (2009a).

52. Farooq, M. Wahid, A. Basra, S. M. A. \& Shahzad, I. D. Improving water relations and gas exchange with brassinosteroids in rice under drought stress. J. Agron. Crop Sci. 195, 262-269 (2009b).

\section{Acknowledgements}

This research was supported by Key Technology program R\&D of China; National natural science Foundation of China (Projects No.31272191, 31372091, and 30871735) and MOA Special fund for Horticulture scientific Research in the public interest of China, Harbin.

\section{Author contributions}

S.S. and C.Y. initiated and designed the research, S.S. performed the experiments, S.S., C.Y., and S.F., analyzed the data and wrote the manuscript, G.C., S.A., S.F., and C.Y. revised and edited the manuscript and also provided advice on the experiments.

\section{Competing interests}

The authors declare no competing interests.

\section{Additional information}

Correspondence and requests for materials should be addressed to C.Y.

Reprints and permissions information is available at www.nature.com/reprints.

Publisher's note Springer Nature remains neutral with regard to jurisdictional claims in published maps and institutional affiliations. 
(c) (i) Open Access This article is licensed under a Creative Commons Attribution 4.0 International License, which permits use, sharing, adaptation, distribution and reproduction in any medium or format, as long as you give appropriate credit to the original author(s) and the source, provide a link to the Creative Commons license, and indicate if changes were made. The images or other third party material in this article are included in the article's Creative Commons license, unless indicated otherwise in a credit line to the material. If material is not included in the article's Creative Commons license and your intended use is not permitted by statutory regulation or exceeds the permitted use, you will need to obtain permission directly from the copyright holder. To view a copy of this license, visit http://creativecommons.org/licenses/by/4.0/.

(C) The Author(s) 2020 